\title{
SYNTHESIS, CHARACTERIZATION AND ELECTROCHEMISTRY OF HETEROBIMETALLIC COMPLEXES CONTAINING MOLYBDENUM(II) NITROSYL AND MANGANESE(II)-SCHIFF BASE CENTERS
}

\author{
R. Odhiambo ${ }^{1}$, G.K. Muthakia ${ }^{1}$ and S.M. Kagwanja ${ }^{2 *}$ \\ ${ }^{1}$ Department of Chemistry, Kenyatta University, P.O. Box 43844-00200, Nairobi, Kenya \\ ${ }^{2}$ Chuka University College, P.O. Box 109-60400, Chuka, Kenya
}

(Received September 28, 2008; revised October 8, 2009)

\begin{abstract}
New complexes derived from the reaction of $\mathrm{Mo}(\mathrm{NO}) \mathrm{T}_{\mathrm{p}}{ }^{*} \mathrm{Cl}_{2} ; \mathrm{T}_{\mathrm{p}}{ }^{*}=\operatorname{tris}(3,5$-dimethylpyrazolyl) borate with a series of manganese(II) Schiff bases have been synthesized. Characterization by UV, IR, MS and elemental analysis support their formulations. Cyclic and differential pulse voltammograms of manganese(II) Schiff base monometallic complexes exhibit one reduction peak which may be associated with the reduction of the manganese(II) center. In $\mathrm{CH}_{3} \mathrm{CN}$ solutions, the molybdenum(II)-manganese(II) bimetallic complexes showed two reversible reduction peaks which are associated with the reduction of the molybdenum and manganese centers. In $\mathrm{CH}_{2} \mathrm{Cl}_{2}$, only the reduction of molybdenum(II) center exhibited reversibility while the reduction of manganese(II) center was irreversible. These observations demonstrate that reduction potentials for bimetallic complexes are solvent dependent.
\end{abstract}

KEY WORDS: Tetradentate N,N',O,O, Schiff base ligands, Monometallic manganese(II) Schiff base complexes, Bimetallic, $\mathrm{Mn}(\mathrm{II})-\mathrm{Mo}(\mathrm{NO}) \mathrm{T}_{\mathrm{p}}{ }^{*} \mathrm{Cl}_{2}\left[\mathrm{~T}_{\mathrm{p}}{ }^{*}=\right.$ tris(3,5-dimethylpyrazolyl) borate $]$ complexes

\section{INTRODUCTION}

For a considerable time, there has been a sustained interest in the synthesis and understanding of the ability of multiatom bridging ligands to mediate electron exchange between metal centres in polynuclear metal complexes. Such exchange coupling phenomenon is important in inorganic and materials chemistry [1-3]. For this reason, many research teams have directed their efforts to the synthesis of polynuclear systems which have novel or useful properties. In such systems, electrochemical [4], photochemical [5] and magnetic [6] interactions between adjacent or remote metal centres depend on transfer of one or more electrons between two interacting metal centres in the same complex [7].

Electron transfer in such systems is mediated through a bridging ligand and it is therefore important to understand the role played by the bridging ligand in the interaction between metal centres. The ability of the bridging ligand to mediate one-electron transfer across the system may offer a reasonable guide to its usefulness in the transport of more electrons in a nanoscopic circuit $[8,9]$.

The versatility with which polynuclear species are synthesized in addition to the concepts developed in mixed valence compounds has stimulated production of a wide variety of species with relevance to biomimetic and/or molecular electronic behavior [10]. Generation of such compounds initially involves synthesis of simple prototype binuclear complexes, which can serve as basic units for construction of larger molecules.

$\left[\mathrm{Mo}(\mathrm{NO}) \mathrm{T}_{\mathrm{p}}{ }^{*} \mathrm{Cl}_{2}\right] \mathrm{T}_{\mathrm{p}}{ }^{*}=\operatorname{tris}(3,5$-dimethylpyrazolyl $)$ borate, a well characterized and readily synthesized precursor compound, affords a convenient vehicle for generating polynuclear bimetallic species that exhibit interesting redox, photochemical and optical properties [11]. Compounds containing these fragments linked by $\left(\mathrm{OC}_{6} \mathrm{H}_{4} \mathrm{O}\right)^{2-}$ and $\left(\mathrm{NHC}_{6} \mathrm{H}_{4} \mathrm{NH}\right)^{2-}$ bridging ligands between two molybdenum centres have been synthesized. They exhibit large electronic

*Corresponding author. E-mail: smkagwanja@gmail.com 
interactions between the remote molybdenum centres which however decreases substantially as the bridging ligand is lengthened in compounds such as $\left[\left\{\mathrm{Mo}(\mathrm{NO}) \mathrm{T}_{\mathrm{p}}{ }^{*} \mathrm{Cl}\right\}_{2}\left(\mathrm{OC}_{6} \mathrm{H}_{4} \mathrm{XC}_{6} \mathrm{H}_{4} \mathrm{O}\right)\right]$, where $\mathrm{X}=\mathrm{CH}_{2}, \mathrm{O}[12]$.

In our previous studies we have reported the synthesis and electrochemical properties of a variety of heterotrinuclear species of type 1 [13] and heterobinuclear species of type 2 [14, 15] in which the $\left[\mathrm{Mo}(\mathrm{NO}) \mathrm{T}_{\mathrm{p}}{ }^{*} \mathrm{Cl}\right]^{+}$metal fragment is linked to a guest cation through a variety of Schiff base ligands (with a saturated linkage at B). In these systems we have shown that the reduction potential of the $\mathrm{Mo}(\mathrm{NO})^{3+}$ moiety is slightly influenced by the type of metal ion complexed in the tetradentate Schiff base cavity. Earlier work on type $\mathbf{2}$ complexes with zinc(II) and copper(II) ions as guest cations demonstrated that the molybdated zinc(II) Schiff base complexes reduce at potentials that are more negative than their corresponding copper(II) analogues $[14,15]$.

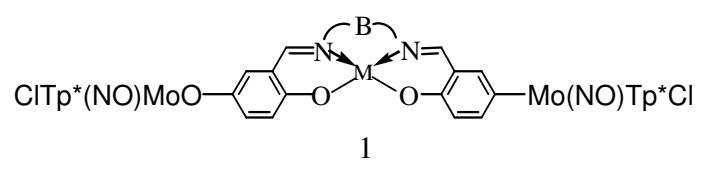

$\mathrm{B}=\mathrm{C}_{6} \mathrm{H}_{4},\left(\mathrm{CH}_{2}\right)_{\mathrm{n}}, \mathrm{n}=2-5 ; \mathrm{M}=\mathrm{Cu}, \mathrm{Ni}$ or $\mathrm{Pd}$

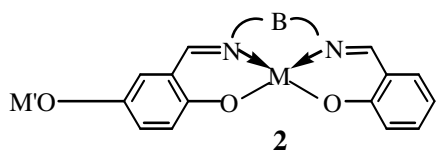

$$
\mathrm{B}=\left(\mathrm{CH}_{2}\right)_{\mathrm{n}}, \mathrm{n}=2-4 ; \mathrm{M}=\mathrm{H}_{2}, \mathrm{Zn} \text { or } \mathrm{Cu} ; \mathrm{M}^{\prime}=\mathrm{H} \text { or }\left[\mathrm{Mo}(\mathrm{NO}) \mathrm{T}_{\mathrm{p}}{ }^{*} \mathrm{Cl}\right]^{+}
$$

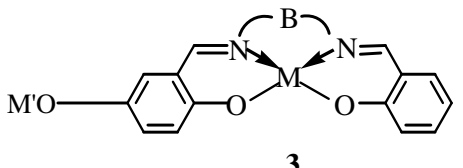

3

$$
\mathrm{B}=\mathrm{C}_{6} \mathrm{H}_{4},\left(\mathrm{CH}_{2}\right)_{\mathrm{n}}, \mathrm{n}=2-4 ; \mathrm{M}=\mathrm{H}_{2} \text { or } \mathrm{Mn}, \mathrm{M}^{\prime}=\text { para or meta } \mathrm{H} \text { or }\left[\mathrm{Mo}(\mathrm{NO}) \mathrm{T}_{\mathrm{p}}^{*} \mathrm{Cl}\right]^{+}
$$

Because of our interest to understand the effect of other first row transition elements complexed in the tetradentate Schiff base cavity, the nature of the linkage at $\mathrm{B}$ and the position of substitution of $\left[\mathrm{Mo}(\mathrm{NO}) \mathrm{T}_{\mathrm{p}}{ }^{*} \mathrm{Cl}\right]^{+}$on the phenoxide ring of the Schiff base on the redox behaviour of the remote $\left[\mathrm{Mo}(\mathrm{NO}) \mathrm{T}_{\mathrm{p}}{ }^{*} \mathrm{Cl}\right]^{+}$metal fragment, we now describe the preparation, spectral characterization and electrochemical behavior of a variety of para $\left[\mathrm{Mo}(\mathrm{NO}) \mathrm{T}_{\mathrm{p}}{ }_{\mathrm{*}} \mathrm{Cl}\right]^{+}-$ $\mathrm{Mn}$ (II) Schiff base complexes of type 3 .

\section{Materials}

\section{EXPERIMENTAL}

Commercial reagents obtained from Aldrich Chemical Co. Ltd. (UK) were used as supplied while the solvents were carefully dried, deoxygenated and distilled prior to use. Manganese(II) acetate tetrahydrate was dried in a desiccator over phosphorous(V) oxide for 24 hours. The percentage yields are quoted relative to the moles of the starting materials.

All synthetic reactions except those involving the Schiff bases and the monometallic Schiff base complexes were carried out under dry nitrogen. The Schiff bases that turned oily on evaporating in vacuo were triturated with $\mathrm{Et}_{2} \mathrm{O}$ to form solids. The precursor complex $\mathrm{Mo}(\mathrm{NO}) \mathrm{T}_{\mathrm{p}}{ }^{*} \mathrm{Cl}_{2}$ was prepared according to the literature method but with slight modifications 
[16]. All the bimetallic complexes were stable enough to be purified by column chromatography with silica gel as the stationary phase and $n-\mathrm{C}_{6} \mathrm{H}_{14}$ or $\mathrm{CH}_{2} \mathrm{Cl}_{2}$ as the eluants.

\section{Physical measurements}

IR spectral data were obtained on a Shimadzu FTIR-8400 spectrometer while electronic spectra were recorded on Unicam U2000. Mass spectra were conducted using a Bruker Bio Apex FTMS fitted with an analytical electrospray source while elemental analyses were carried out with a CHN elemental analyzer model vario EL3 (Elementar). Cyclic and differential pulse experiments were performed on an Autolab potentiostat/galvanostat PGSTAT 12 electrochemical analyzer equipped with a three electrodes assembly. Glassy carbon was used as the working electrode and $\mathrm{Ag} / \mathrm{AgCl}$ as the reference electrode. A platinum wire was used as the counter electrode. Solutions in DMSO, $\mathrm{CH}_{3} \mathrm{CN}$ and $\mathrm{CH}_{2} \mathrm{Cl}_{2}$ were ca $1 \times 10^{-3} \mathrm{M}$ in the complex with $0.1 \mathrm{M}\left[\mathrm{Bu}_{4} \mathrm{~N}\right] \mathrm{PF}_{6}$ as the supporting electrolyte. Although ferrocene was used as an internal standard, the formal redox potentials were calculated as the average of anodic and cathodic peak potentials versus $\mathrm{Ag} / \mathrm{AgCl}$.

\section{Synthesis of Schiff base ligands}

Procedure la for the synthesis of the Schiff base [(3), $\left.M=H_{2}, M^{\prime}=H, B=\left(C_{6} H_{4}\right)\right]$. To a solution of 2,5-dihydroxybenzaldehyde $(1.50 \mathrm{~g}, 10.9 \mathrm{mmoles})$ and salicylaldehyde $(1.15 \mathrm{~mL}$, 10.9 mmoles) in $50 \mathrm{~mL}$ absolute ethanol was added drop wise a solution of $o-\mathrm{NH}_{2} \mathrm{C}_{6} \mathrm{H}_{4} \mathrm{NH}_{2}$ (1.17 g, 10.9 mmoles) in $10 \mathrm{~mL}$ absolute ethanol. The solution mixture was refluxed for $2 \mathrm{~h}$, filtered while hot and the excess solvent removed in vacuo to give a red, oily liquid. On triturating with $\mathrm{Et}_{2} \mathrm{O}$, a red solid was obtained. It was thoroughly washed with $\mathrm{Et}_{2} \mathrm{O}$ and dried in air for 2 days (yield; $3.30 \mathrm{~g}, 91.7 \%$ ).

The synthesis of the Schiff base [(3), $\left.\mathrm{M}=\mathrm{H}_{2}, \mathrm{M}^{\prime}=\mathrm{H}, \mathrm{B}=\left(\mathrm{CH}_{2}\right)_{2}\right]$. A procedure similar to 1a was followed by using 1,2- $\mathrm{NH}_{2}\left(\mathrm{CH}_{2}\right)_{2} \mathrm{NH}_{2}$ instead of $o-\mathrm{NH}_{2} \mathrm{C}_{6} \mathrm{H}_{4} \mathrm{NH}_{2}(0.73 \mathrm{~mL}, 10.9$ mmoles $)$. The solution mixture was refluxed for $2 \mathrm{~h}$ and then filtered while hot. The orange filtrate was cooled and excess solvent evaporated in vacuo to yield an orange solid which was then thoroughly washed with $\mathrm{Et}_{2} \mathrm{O}$ and allowed to dry for 2 days (yield; $2.90 \mathrm{~g}, 95.0 \%$ ).

The synthesis of the Schiff base [(3), $\left.M=\mathrm{H}_{2}, M^{\prime}=\mathrm{H}, \mathrm{B}=\left(\mathrm{CH}_{2}\right)_{3}\right]$. A procedure similar to 1a was followed using 1,3- $\mathrm{NH}_{2}\left(\mathrm{CH}_{2}\right)_{3} \mathrm{NH}_{2}(0.9 \mathrm{~mL}, 10.86$ mmoles $)$ in place of $o-\mathrm{NH}_{2} \mathrm{C}_{6} \mathrm{H}_{4} \mathrm{NH}_{2}$. The solution mixture was refluxed for $2 \mathrm{~h}$, filtered while hot and excess solvent in the filtrate evaporated in vacuo to give a red oil which on triturating with $\mathrm{Et}_{2} \mathrm{O}$ afforded an orange solid. The solid obtained was thoroughly washed with $\mathrm{Et}_{2} \mathrm{O}$ and dried in air for 2 days (yield; $2.60 \mathrm{~g}$, $80.2 \%)$.

The synthesis of the Schiff base [(3), $\left.\mathrm{M}=\mathrm{H}_{2}, \mathrm{M}^{\prime}=\mathrm{H}, \mathrm{B}=\left(\mathrm{CH}_{2}\right)_{4}\right]$. A procedure similar to 1a was followed using $1,4-\mathrm{NH}_{2}\left(\mathrm{CH}_{2}\right)_{4} \mathrm{NH}_{2}(1.10 \mathrm{~mL}, 10.86$ mmoles $)$ in place of $o$ $\mathrm{NH}_{2} \mathrm{C}_{6} \mathrm{H}_{4} \mathrm{NH}_{2}$. The mixture was refluxed for $2 \mathrm{~h}$ and then filtered while hot. The orange filtrate was cooled and excess solvent in the filtrate evaporated in vacuo to afford a solid which was then washed with $\mathrm{Et}_{2} \mathrm{O}$ and then allowed to dry for 2 days (yield; $2.70 \mathrm{~g}, 79.6 \%$ ).

Synthesis of monometallic complexes

Procedure $1 b$ for the synthesis of manganese(II)-Schiff base complex [(3), $M=M n, M^{\prime}=H, B$ $\left.=C_{6} H_{4}\right]$. A solution of manganese(II) acetate tetrahydrate $(0.64 \mathrm{~g}, 2.60$ mmoles $)$ in $30 \mathrm{~mL}$ absolute ethanol was added dropwise to a solution of Schiff base $\left[(\mathbf{3}), \mathrm{M}=\mathrm{H}_{2}, \mathrm{M}^{\prime}=\mathrm{H}, \mathrm{B}=\right.$ 
$\left.\left(\mathrm{C}_{6} \mathrm{H}_{4}\right)\right](0.86 \mathrm{~g}, 2.60$ mmoles$)$ in $30 \mathrm{~mL}$ absolute ethanol. The reaction mixture which turned brown on thorough shaking was refluxed for $30 \mathrm{~h}$, cooled and then filtered. The black residue obtained was washed with ethanol $(3 \times 50 \mathrm{~mL})$ followed by $\mathrm{Et}_{2} \mathrm{O}(3 \times 50 \mathrm{~mL})$ and then dried in the air for $1 \mathrm{~h}$ (yield; $0.50 \mathrm{~g}, 50.5 \%$ ).

The synthesis of manganese(II)-Schiff base complex [(3), $\left.M=\mathrm{Mn}, \mathrm{M}^{\prime}=\mathrm{H}, \mathrm{B}=\left(\mathrm{CH}_{2}\right)_{2}\right]$. This compound was prepared in a manner similar to procedure $1 \mathrm{~b}$ using Schiff base $\left[(\mathbf{3}), \mathrm{M}=\mathrm{H}_{2}, M^{\prime}\right.$ $=\mathrm{H}, \mathrm{B}=\left(\mathrm{CH}_{2}\right)_{2}(0.74 \mathrm{~g}, 2.60$ mmoles$)$. The reaction mixture which turned brown on thorough shaking was refluxed for 2 days forming a black residue which was then filtered off, washed with ethanol $(3 \times 50 \mathrm{~mL})$ followed by $\mathrm{Et}_{2} \mathrm{O}(3 \times 50 \mathrm{~mL})$ and then allowed to dry for $1 \mathrm{~h}$ (yield; $0.65 \mathrm{~g}, 72.3 \%)$.

The synthesis of manganese(II)-Schiff base complex [(3), $\left.M=\mathrm{Mn}, \mathrm{M}^{\prime}=\mathrm{H}, \mathrm{B}=\left(\mathrm{CH}_{2}\right)_{3}\right]$. This compound was prepared in a manner similar to procedure $1 \mathrm{~b}$ using Schiff base $\left[(\mathbf{3}), \mathrm{M}=\mathrm{H}_{2}\right.$, $\left.M^{\prime}=\mathrm{H}, \mathrm{B}=\left(\mathrm{CH}_{2}\right)_{3}\right](0.77 \mathrm{~g}, 2.60$ mmoles $)$. The brown solution formed on thorough shaking was refluxed for $36 \mathrm{~h}$, cooled and then filtered. The black residue obtained was thoroughly washed with ethanol $(3 \times 50 \mathrm{~mL})$ followed by $\mathrm{Et}_{2} \mathrm{O}(3 \times 50 \mathrm{~mL})$ and finally dried in the air for 1 h (yield; $0.64 \mathrm{~g}, 70.8 \%$ ).

The synthesis of manganese(II)-Schiff base complex [(3), $\left.M=\mathrm{Mn}, \mathrm{M}^{\prime}=\mathrm{H}, \mathrm{B}=\left(\mathrm{CH}_{2}\right)_{4}\right]$. This compound was prepared in a manner similar to procedure $1 \mathrm{~b}$ using Schiff base $\left[(\mathbf{3}), \mathrm{M}=\mathrm{H}_{2}, \mathrm{M}^{\prime}\right.$ $\left.=\mathrm{H}, \mathrm{B}=\left(\mathrm{CH}_{2}\right)_{4}\right](0.81 \mathrm{~g}, 2.60 \mathrm{mmoles})$. The reaction mixture immediately turned brown on thorough shaking. On refluxing for $24 \mathrm{~h}$, it formed a dark red solid which was filtered off, washed with ethanol $(3 \times 50 \mathrm{~mL})$ and $\mathrm{Et}_{2} \mathrm{O}(3 \times 50 \mathrm{~mL})$ and then dried for $1 \mathrm{~h}$ (yield $0.50 \mathrm{~g}$, $53.4 \%)$.

\section{Synthesis of bimetallic complexes}

The synthesis of Mo-Mn(II) bimetallic complex [(3), $\left.M=M n, M^{\prime}=M o(N O) T_{p}{ }^{*} C l, B=C_{6} H_{4}\right]$. To a suspension of $\left[(3), M=M n, M^{\prime}=\mathrm{H}, \mathrm{B}=\mathrm{C}_{6} \mathrm{H}_{4}\right](0.23 \mathrm{~g}, 0.60$ mmoles $)$ in $50 \mathrm{~mL}$ dry toluene was added a solution of $\mathrm{Mo}(\mathrm{NO}) \mathrm{Tp}^{*} \mathrm{Cl}_{2}(0.30 \mathrm{~g}, 0.60 \mathrm{mmoles})$ in $50 \mathrm{~mL}$ dry toluene followed by a few drops of $\mathrm{Et}_{3} \mathrm{~N}$. The mixture was refluxed for 7 days under nitrogen, turning deep red in color. It was then filtered while hot, cooled and the filtrate evaporated in vacuo, forming a brown solid. The solid was dissolved in a minimum amount of $\mathrm{CH}_{2} \mathrm{Cl}_{2}$ and then chromatographed on a column packed with silica gel. The major red fraction was eluted using 1 $\%$ THF in $\mathrm{CH}_{2} \mathrm{Cl}_{2}$. The eluate obtained was evaporated in vacuo to afford red crystals which were washed with $n-\mathrm{C}_{6} \mathrm{H}_{14}$ and then dried in air for 1 day (yield; $0.21 \mathrm{~g}, 41.2 \%$ ).

The synthesis of Mo-Mn(II) bimetallic complex [(3), $\left.\mathrm{M}=\mathrm{Mn}, \mathrm{M}^{\prime}=\mathrm{Mo}(\mathrm{NO}) \mathrm{T}_{p}{ }^{*} \mathrm{Cl}, \mathrm{B}=\left(\mathrm{CH}_{2}\right)_{2}\right]$. A procedure similar to the above was followed using $\left[(\mathbf{3}), \mathbf{M}=\mathrm{Mn}, \mathbf{M}^{\prime}=\mathrm{H}, \mathrm{B}=\left(\mathrm{CH}_{2}\right)_{2}\right](0.20$ $\mathrm{g}, 0.60 \mathrm{mmoles})$ and $\mathrm{Mo}(\mathrm{NO}) \mathrm{Tp} * \mathrm{Cl}_{2}(0.30 \mathrm{~g}, 0.60 \mathrm{mmoles})$. The mixture was refluxed for 7 days under nitrogen, turning deep red in color. It was then filtered while hot, cooled and the filtrate evaporated in vacuo, forming a brown solid. The solid was dissolved in a minimum amount of $\mathrm{CH}_{2} \mathrm{Cl}_{2}$ and then chromatographed on a column packed with silica gel. The major red fraction was eluted using $1 \% n-\mathrm{C}_{6} \mathrm{H}_{14}$ in $\mathrm{CH}_{2} \mathrm{Cl}_{2}$ (v/v). The eluate obtained was evaporated in vacuo to afford red crystals which were washed with $n-\mathrm{C}_{6} \mathrm{H}_{14}$ and then dried in air for 1 day (yield; $0.22 \mathrm{~g}, 45.8 \%$ ).

The synthesis of Mo-Mn(II) bimetallic complex [(3), $\left.\mathrm{M}=\mathrm{Mn}, \mathrm{M}^{\prime}=\mathrm{Mo}(\mathrm{NO}) \mathrm{T}_{p}{ }^{*} \mathrm{Cl}, \mathrm{B}=\left(\mathrm{CH}_{2}\right)_{3}\right]$. A procedure similar to the above was followed using $\left[(\mathbf{3}), \mathbf{M}=\mathrm{Mn}, \mathrm{M}^{\prime}=\mathrm{H}, \mathrm{B}=\left(\mathrm{CH}_{2}\right)_{3}\right](0.21$ $\mathrm{g}, 0.60 \mathrm{mmoles})$ and $\mathrm{Mo}(\mathrm{NO}) \mathrm{Tp}^{*} \mathrm{Cl}_{2}(0.30 \mathrm{~g}, 0.60 \mathrm{mmoles})$. The mixture was refluxed for 6 
days under nitrogen, turning deep red in color. It was then filtered while hot, cooled and the filtrate evaporated in vacuo, forming a brown solid. The solid was dissolved in a minimum amount of $\mathrm{CH}_{2} \mathrm{Cl}_{2}$ and then chromatographed on a column packed with silica gel. The major red fraction was eluted using $10 \% n-\mathrm{C}_{6} \mathrm{H}_{14}$ in $\mathrm{CH}_{2} \mathrm{Cl}_{2}(\mathrm{v} / \mathrm{v})$. The eluate obtained was evaporated in vacuo to afford red crystals which were washed with $n-\mathrm{C}_{6} \mathrm{H}_{14}$ and then dried in air for 1 day (yield; $0.21 \mathrm{~g}, 42.9 \%$ ).

The synthesis of $\mathrm{Mo}-\mathrm{Mn}(\mathrm{II})$ bimetallic complex [(3), $\left.\mathrm{M}=\mathrm{Mn}, \mathrm{M}^{\prime}=\mathrm{Mo}(\mathrm{NO}) \mathrm{T}_{p}{ }^{*} \mathrm{Cl}, \mathrm{B}=\left(\mathrm{CH}_{2}\right)_{4}\right]$. A procedure similar to above was followed using [(3), $\left.\mathrm{M}=\mathrm{Mn}, \mathrm{M}^{\prime}=\mathrm{H}, \mathrm{B}=\left(\mathrm{CH}_{2}\right)_{4}\right](0.22 \mathrm{~g}$, 0.60 mmoles $)$ and $\mathrm{Mo}(\mathrm{NO}) \mathrm{Tp}^{*} \mathrm{Cl}_{2}(0.30 \mathrm{~g}, 0.60 \mathrm{mmoles})$. The mixture was refluxed for 6 days under nitrogen, turning deep red. It was then filtered while hot, cooled and the filtrate evaporated in vacuo, forming a brown solid. The solid was dissolved in a minimum amount of $\mathrm{CH}_{2} \mathrm{Cl}_{2}$ and then chromatographed on a column packed with silica gel. The first minor yellow fraction was eluted using $n$-hexane and discarded. The second major red fraction was eluted using $10 \% n-\mathrm{C}_{6} \mathrm{H}_{14}$ in $\mathrm{CH}_{2} \mathrm{Cl}_{2}$ (v/v). The eluate obtained was evaporated in vacuo to afford red crystals which were washed with $n-\mathrm{C}_{6} \mathrm{H}_{14}$ and then dried in air for 1 day (yield; $0.22 \mathrm{~g}, 44.9 \%$ ).

\section{RESULTS AND DISCUSSION}

Microanalytical data, conductance values in various solvents and mass spectral data obtained for the new para functionalized mononuclear manganese(II)-Schiff base complexes and their corresponding binuclear complexes are summarized in Table 1 and are consistent with their proposed formulations.

Table 1. Analytical, mass spectral and conductance data for type 3 complexes [(3), $\mathrm{M}=\mathrm{Mn}, \mathrm{M}^{\prime}=\mathrm{H}$ or $\mathrm{Mo}(\mathrm{NO}) \mathrm{T}_{\mathrm{p}}{ }^{*} \mathrm{Cl}, \mathrm{B}=$ hydrocarbyl].

\begin{tabular}{|c|c|c|c|c|c|c|c|c|c|c|}
\hline \multicolumn{3}{|c|}{ Compound } & $\begin{array}{c}\text { Solvent } \\
\mathrm{a}\end{array}$ & \multicolumn{3}{c|}{ Found (calculated) \% } & \multicolumn{2}{c|}{$\begin{array}{c}\text { Mass } \\
\text { spec. }\end{array}$} & \multicolumn{3}{c|}{$\begin{array}{c}\text { Conductance } \\
\Omega^{-1} \mathrm{~cm}^{2} \mathrm{~mol}^{-1}\end{array}$} \\
\hline $\mathrm{M}^{\prime}$ & $\mathrm{B}$ & $\mathrm{M}$ & & $\mathrm{C}$ & $\mathrm{H}$ & $\mathrm{N}$ & {$[\mathrm{M}]^{+}$} & $\mathrm{DMF}$ & $\mathrm{DMSO}$ & $\mathrm{CH}_{3} \mathrm{CN}$ \\
\hline $\mathrm{H}$ & $\mathrm{C}_{6} \mathrm{H}_{4}$ & $\mathrm{Mn}$ & 0 & $62.5(62.3)$ & $4.1(3.6)$ & $7.5(7.3)$ & 385 & 2.67 & 4.58 & 1.47 \\
\hline $\mathrm{H}$ & $\left(\mathrm{CH}_{2}\right)_{2}$ & $\mathrm{Mn}$ & 0 & $56.9(57.0)$ & $4.7(4.2)$ & $8.2(8.3)$ & 337 & 3.28 & 6.22 & 1.48 \\
\hline $\mathrm{H}$ & $\left(\mathrm{CH}_{2}\right)_{3}$ & $\mathrm{Mn}$ & 0 & $58.9(58.1)$ & $4.9(4.6)$ & $7.9(8.0)$ & 351 & 1.52 & 1.34 & 1.27 \\
\hline $\mathrm{H}$ & $\left(\mathrm{CH}_{2}\right)_{4}$ & $\mathrm{Mn}$ & 0 & $59.5(59.2)$ & $5.2(4.9)$ & $8.0(7.9)$ & 365 & 1.12 & 4.88 & 1.62 \\
\hline $\mathrm{Mo}(\mathrm{NO}) \mathrm{T}_{\mathrm{p}}{ }^{*} \mathrm{Cl}$ & $\mathrm{C}_{6} \mathrm{H}_{4}$ & $\mathrm{Mn}$ & $1.0 \mathrm{H}_{2} \mathrm{O}$ & $48.9(48.6)$ & $5.2(4.7)$ & $14.7(14.6)$ & & 7.53 & 2.58 & 7.21 \\
\hline $\mathrm{Mo}(\mathrm{NO}) \mathrm{T}_{\mathrm{p}}{ }^{*} \mathrm{Cl}$ & $\left(\mathrm{CH}_{2}\right)_{2}$ & $\mathrm{Mn}$ & $1.0 \mathrm{H}_{2} \mathrm{O}$ & $45.8(45.60)$ & $5.4(5.0)$ & $15.6(15.5)$ & & 10.01 & 3.11 & 6.20 \\
\hline $\mathrm{Mo}(\mathrm{NO}) \mathrm{T}_{\mathrm{p}}{ }^{*} \mathrm{Cl}$ & $\left(\mathrm{CH}_{2}\right)_{3}$ & $\mathrm{Mn}$ & $1.0 \mathrm{H}_{2} \mathrm{O}$ & $46.7(46.4)$ & $5.7(5.2)$ & $15.4(15.2)$ & & 7.52 & 1.10 & 7.33 \\
\hline $\mathrm{Mo}(\mathrm{NO}) \mathrm{T}_{\mathrm{p}}{ }^{*} \mathrm{Cl}$ & $\left(\mathrm{CH}_{2}\right)_{4}$ & $\mathrm{Mn}$ & $1.0 \mathrm{H}_{2} \mathrm{O}$ & $47.2(46.9)$ & $5.6(5.3)$ & $15.0(14.9)$ & & 6.72 & 2.99 & 9.11 \\
\hline
\end{tabular}

${ }^{a}$ Crystallized solvent molecules.

Conductance measurements in DMSO, DMF and $\mathrm{CH}_{3} \mathrm{CN}$ solvents indicate that all the $\Lambda_{\mathrm{M}}$ values are less than the quoted values for $1: 1$ type of electrolytes at $10^{-3} \mathrm{M}$ in complexes, suggesting that they are all non-electrolytes (Table 1).

Microanalytical data suggest that while manganese-Schiff base mononuclear complexes were isolated without water of crystallization, their corresponding bimetallic complexes were isolated as water solvated complexes.

\section{IR and electronic spectra}

IR spectral data for free Schiff bases, their mononuclear manganese and bimetallic derivatives are given in Table 2 . 
Table 2. Selected I.R and electronic spectral data for Type 3 complexes [(3), $M=\mathrm{H}_{2}$ or $\mathrm{Mn}, \mathrm{M}^{\prime}=\mathrm{H}$ or $\mathrm{Mo}(\mathrm{NO}) \mathrm{T}_{\mathrm{p}}{ }^{*} \mathrm{Cl}, \mathrm{B}=$ hydrocarbyl].

\begin{tabular}{|c|c|c|c|c|c|c|c|c|c|}
\hline \multicolumn{3}{|c|}{ Compound } & \multicolumn{6}{|c|}{ IR spectral data $\left(\mathrm{cm}^{-1}\right)$} & \multirow{2}{*}{$\begin{array}{l}\text { UV-Vis spectral data } \\
\lambda(\mathrm{nm}),(\varepsilon) \mathrm{M}^{-1} \mathrm{~cm}^{-1}\end{array}$} \\
\hline$M^{\prime}$ & B & M & $v(\mathrm{C}=\mathrm{N})$ & $v(\mathrm{ph} . \mathrm{CO})$ & $v(\mathrm{MO})$ & $v(\mathrm{BH})$ & $v(\mathrm{MN})$ & $v(\mathrm{NO})$ & \\
\hline $\mathrm{H}$ & $\mathrm{C}_{6} \mathrm{H}_{4}$ & $\mathrm{H}_{2}$ & 1617 & 1272 & & & & & $\begin{array}{l}283 \text { (7680), } 316(4390), \\
330 \text { (2039) }\end{array}$ \\
\hline $\mathrm{H}$ & $\left(\mathrm{CH}_{2}\right)_{2}$ & $\mathrm{H}_{2}$ & 1637 & 1278 & & & & & $256(6826), 340(5650)$ \\
\hline $\mathrm{H}$ & $\left(\mathrm{CH}_{2}\right)_{3}$ & $\mathrm{H}_{2}$ & 1637 & 1279 & & & & & $256(7336), 320(5281)$ \\
\hline $\mathrm{H}$ & $\left(\mathrm{CH}_{2}\right)_{4}$ & $\mathrm{H}_{2}$ & 1636 & 1278 & & & & & $256(6761), 345$ (4647) \\
\hline $\mathrm{H}$ & $\mathrm{C}_{6} \mathrm{H}_{4}$ & Mn & 1633 & 1290 & 405 & & 502 & & $\begin{array}{l}260 \text { (8445), } 293 \text { (6049), } \\
320 \text { (3529) }\end{array}$ \\
\hline $\mathrm{H}$ & $\left(\mathrm{CH}_{2}\right)_{2}$ & Mn & 1629 & 1291 & 406 & & 501 & & $\begin{array}{l}260 \text { (6329), } 280 \text { (6727), } \\
346 \text { (4298), } 400 \text { (414) }\end{array}$ \\
\hline $\mathrm{H}$ & $\left(\mathrm{CH}_{2}\right)_{3}$ & $\mathrm{Mn}$ & 1634 & 1294 & 407 & & 503 & & $\begin{array}{l}262 \text { (7325), } 310 \text { (6899), } \\
350 \text { (4663), } 401 \text { (458) } \\
\end{array}$ \\
\hline $\mathrm{H}$ & $\left(\mathrm{CH}_{2}\right)_{4}$ & $\mathrm{Mn}$ & 1636 & 1295 & 403 & & 516 & & $\begin{array}{l}262 \text { (6709), } 324 \text { (5413), } \\
350 \text { (4576), } 404 \text { (481) }\end{array}$ \\
\hline $\mathrm{Mo}(\mathrm{NO}) \mathrm{T}_{\mathrm{p}}{ }^{*} \mathrm{Cl}$ & $\mathrm{C}_{6} \mathrm{H}_{4}$ & $\mathrm{Mn}$ & - & 1265 & 425 & 2549 & 539 & 1659 & $\begin{array}{l}262 \text { (7111), } 314 \text { (6979), } \\
416 \text { (5403), } 510 \text { (407) }\end{array}$ \\
\hline $\mathrm{Mo}(\mathrm{NO}) \mathrm{T}_{\mathrm{p}}{ }^{*} \mathrm{Cl}$ & $\left(\mathrm{CH}_{2}\right)_{2}$ & $\mathrm{Mn}$ & - & 1276 & 426 & 2552 & b & 1656 & $\begin{array}{l}262(8441), 320(5034), \\
372(689), 498(469)\end{array}$ \\
\hline $\mathrm{Mo}(\mathrm{NO}) \mathrm{T}_{\mathrm{p}}{ }^{*} \mathrm{Cl}$ & $\left(\mathrm{CH}_{2}\right)_{3}$ & $\mathrm{Mn}$ & - & 1282 & 425 & 2555 & $\mathrm{~b}$ & 1655 & $\begin{array}{l}262 \text { (7403), } 308 \text { (6057), } \\
474 \text { (480) }\end{array}$ \\
\hline $\mathrm{Mo}(\mathrm{NO}) \mathrm{T}_{\mathrm{p}}{ }^{*} \mathrm{Cl}$ & $\left(\mathrm{CH}_{2}\right)_{4}$ & $\mathrm{Mn}$ & - & 1278 & 426 & 2551 & 529 & 1660 & $\begin{array}{l}264 \text { (8495), } 304 \text { (5581), } \\
475 \text { (494) }\end{array}$ \\
\hline
\end{tabular}

$\mathrm{b}=$ broad band. IR data were obtained as $\mathrm{KBr}$ pellets. UV-vis spectral data for Schiff base were obtained in EtOH while those of the monometallic and bimetallic complexes were obtained in DMSO and $\mathrm{CH}_{2} \mathrm{Cl}_{2}$ solvents, respectively.

The solids exist in both phenolimine and ketoenamine forms [17]. We confirmed the presence of keto enamine form of the solids by the presence of a very weak $v \mathrm{NH}$ at 3057-3070 $\mathrm{cm}^{-1}$ and $v($ phenolic $\mathrm{C}=\mathrm{O})$ which appeared as a shoulder at $1651 \mathrm{~cm}^{-1}$. The weakness of these bands shows that the ketoenamine tautomer was present in very small proportions. The phenolimine tautomer however, exhibited very intense $v(\mathrm{C}=\mathrm{N})$ and $v($ phenolic $\mathrm{C}-\mathrm{O})$ stretching frequency bands which appeared at $1635-1637 \mathrm{~cm}^{-1}$ and $1272-1282 \mathrm{~cm}^{-1}$ as, respectively (Table 2). These values fall within the range of typical stretching frequencies for Schiff bases reported by other workers [18]. The $v(\mathrm{C}=\mathrm{N})$ and $v($ phenolic $\mathrm{C}-\mathrm{O})$ were slightly sensitive to the change in the polymethylene carbon chain length of the Schiff base back bone (B).

For the manganese(II)-Schiff base mononuclear complexes, no band was observed in the region of $1650 \mathrm{~cm}^{-1}$ showing that upon complexation with metal ions, the Schiff base ligands may exist only in the imine form [17]. However the $v(\mathrm{C}=\mathrm{N})$ shifted to lower frequencies in the range $1618-1635 \mathrm{~cm}^{-1}$, the bathochromic shift serving as evidence that the metal ions were coordinated to the $\mathrm{N}_{2} \mathrm{O}_{2}{ }^{2-}$ central cavity in the Schiff bases. Such shifts have been previously observed in $\mathrm{Zn}$ (II) and $\mathrm{Cu}$ (II) complexes of similar Schiff base ligands [14, 15]. Similarly, $v$ (phenolic C-O) shifted to $1291-1298 \mathrm{~cm}^{-1}$ region upon complex formation, confirming the participation of oxygen in the C-O-Mn bond formation. Other notable bands not observed in the Schiff bases but found in manganese Schiff base mononuclear complexes occured in the 403$426 \mathrm{~cm}^{-1}$ and $501-539 \mathrm{~cm}^{-1}$ regions. These may be attributed to $v($ phenolic C-O-Mn) and $v \mathrm{Mn} \leftarrow \mathrm{N}$ chromphores, respectively [19]. On the basis of the IR data for the Schiff bases and their derivative complexes, one can deduce that the metal ions are bonded to the Schiff bases via the phenolic oxygen and imino nitrogen atoms. 
The peaks of interest in the bimetallic complexes of manganese Schiff base mononuclear ligands were $v(\mathrm{C}=\mathrm{N}), v($ phenolic $\mathrm{C}-\mathrm{O}), v(\mathrm{NO})$ and $v(\mathrm{BH})$. These bimetallic complexes exhibited broad peaks in the $2549-2555 \mathrm{~cm}^{-1}$ and $1265-1282 \mathrm{~cm}^{-1}$ (KBr pellets) regions, the peaks being attributable to $v(\mathrm{BH})$ and $v($ phenolic $\mathrm{C}-\mathrm{O})$, respectively. However peaks due to $v(\mathrm{C}=\mathrm{N})$ and $v(\mathrm{NO})$ overlapped to give a broad unsymmetrical band in the $1655-1660 \mathrm{~cm}^{-1}$ region. IR spectral features of bimetallic complexes in solution form exhibited $v(\mathrm{BH})$ and $v$ (phenolic $\mathrm{C}-\mathrm{O}$ ) at 2520$2522 \mathrm{~cm}^{-1}$ and 1261-1265 $\mathrm{cm}^{-1}$, respectively, while $v(\mathrm{C}=\mathrm{N})$ and $v(\mathrm{NO})$ which appeared as a single broad band as $\mathrm{KBr}$ pellet resolved to give two separate peaks at $1606-1608 \mathrm{~cm}^{-1}$ and $1654-1659 \mathrm{~cm}^{-1}$, respectively. The $v(\mathrm{NO})$ in the bimetallic complexes were generally lower than the value obtained for the precursor molecule, $\mathrm{Mo}(\mathrm{NO}) \mathrm{T}_{\mathrm{p}}{ }^{*} \mathrm{Cl}_{2} ; v(\mathrm{NO})=1702 \mathrm{~cm}^{-1}$. This may be due to substantial metal $d_{\pi}-p_{\pi}$ back-donation into nitrosyl (NO) antibonding orbitals, which in effect reduces the NO bond order, thus lowering its stretching frequency. The stretching frequency values for the NO ligand for bimetallic complexes were found to be lower than for bimetallic complexes containing phenolato bridging ligands, whose values fall in the range of $1678-1685 \mathrm{~cm}^{-1}$ [20]. In addition to these bands, four characteristic absorption bands of the pyrazolyl groups occurred in the $1457-1558 \mathrm{~cm}^{-1}$ region.

The electronic spectra of the Schiff base ligands show intense intraligand absorption bands in the 256-345 $\mathrm{nm}$ region (Table 2). Bands at 256-283 nm and 316-345 $\mathrm{nm}$ may be attributed to benzene $\pi-\pi^{*}$ and imine $\pi-\pi^{*}$ transitions, respectively. The corresponding manganese(II)-Schiff base complexes had similar spectral features as the Schiff base ligands except that they exhibit a shift to longer wavelengths (260-404 nm). Mononuclear manganese Schiff base complexes do not show bands due to $d-d$ transitions as expected. This can be attributed to the fact that being a $d^{5}$ system, all the excited states in the manganese(II) chromophore have different spin multiplicity from the ground state causing transitions to be spin - forbidden.

Lengthening of the polymethylene carbon chain backbone in these complexes, results in no observable shift in the wavelength of the bands, as has been observed in similar complexes of copper(II) [15]. This suggests preference for an octahedral structure for the manganese(II) complexes, which is usually rather rigid hence tautomeric or fluxional rearrangements do not occur unless metal-ligand bond breaking is involved. The octahedral configuration for manganese(II) complexes has been established by other workers [21].

Bimetallic complexes displayed additional very weak bands in the $474-510 \mathrm{~nm}$ region. These peaks could be attributed to the presence of the $\left[\mathrm{Mo}(\mathrm{NO}) \mathrm{T}_{\mathrm{p}}{ }^{*} \mathrm{ClO}-\mathrm{Ar}\right]$ chromophore and may be associated with metal-ligand charge transfer (MLCT) between the molybdenum center and the phenoxide (OAr) moiety of the Schiff base ligand. The noticeable decrease in the intensity of these bands may be due to loss of energy to other transitions [15].

\section{Electrochemical studies}

The electrochemical behavior of mononuclear manganese(II)-Schiff base complexes and their corresponding bimetallic complexes were investigated by both cyclic (CV) and differential pulse voltammetry (DPV). Glassy carbon was used as the working electrode and potentials are reported versus $\mathrm{Ag} / \mathrm{AgCl}$ reference electrode. The manganese(II)-Schiff base mono metallic complexes exhibited relatively low solubility in $\mathrm{CH}_{2} \mathrm{Cl}_{2}$ and $\mathrm{CH}_{3} \mathrm{CN}$ solvents and their electrochemical properties were investigated in DMSO only. CV for bimetallic complexes were however investigated in both $\mathrm{CH}_{2} \mathrm{Cl}_{2}$ and $\mathrm{CH}_{3} \mathrm{CN}$ to establish whether their redox potentials are significantly solvent dependent. Electrochemical data determined by cyclic voltammetry for all the complexes are summarized in (Table 3 ).

On scanning from 0.0 to $-1.0 \mathrm{~V}$ and reversing the scan polarity in DMSO, cyclic voltammograms of the $p$-monometallic complexes [ $(3), M=M n, M^{\prime}=H, B=C_{6} H_{4},\left(C_{2}\right)_{n} ; n=$ 2-4], shows similar reduction waves with the reduction potentials for all the complexes falling 
in the range of -0.441 to $-0.445 \mathrm{~V}$. Figure 1 shows a typical cyclic voltammogram of a manganese Schiff base monometallic complex in DMSO.

Table 3. Cyclic voltammetric data for Type 3 complexes $\left[(\mathbf{3}), \mathrm{M}=\mathrm{Mn}, \mathrm{M}^{\prime}=\mathrm{H}\right.$ or $\mathrm{Mo}(\mathrm{NO}) \mathrm{T}_{\mathrm{p}}{ }^{*} \mathrm{Cl}, \mathrm{B}$ hydrocarbyl] in various solvents.

\begin{tabular}{|l|c|c|c|c|c|c|c|c|c|c|c|}
\hline \multicolumn{3}{|c|}{ Compound } & \multicolumn{2}{c|}{ DMSO } & \multicolumn{3}{c|}{$\mathrm{CH}_{3} \mathrm{CN}$} & \multicolumn{5}{c|}{$\mathrm{CH}_{2} \mathrm{Cl}_{2}$} \\
\hline $\mathrm{M}^{\prime}$ & $\mathrm{B}$ & $\mathrm{M}$ & $\mathrm{E}_{1 / 2}{ }^{1}$ & $\mathrm{E}_{\mathrm{a}}{ }^{2}$ & $\mathrm{E}_{1 / 2}{ }^{1}$ & $\mathrm{E}_{1 / 2}{ }^{3}$ & $\mathrm{E}_{\mathrm{a}}{ }^{2}$ & $\mathrm{E}_{\mathrm{c}}{ }^{1}$ & $\mathrm{E}_{1 / 2}{ }^{3}$ & $\mathrm{E}_{\mathrm{a}}{ }^{3}$ & $\mathrm{E}_{\mathrm{a}}{ }^{6}$ \\
\hline $\mathrm{H}$ & $\mathrm{C}_{6} \mathrm{H}_{4}$ & $\mathrm{Mn}$ & -0.441 & 0.562 & & & & & & & \\
\hline $\mathrm{H}$ & $\left(\mathrm{CH}_{2}\right)_{2}$ & $\mathrm{Mn}$ & -0.442 & 0.573 & & & & & & & \\
\hline $\mathrm{H}$ & $\left(\mathrm{CH}_{2}\right)_{3}$ & $\mathrm{Mn}$ & -0.444 & 0.598 & & & & & & & \\
\hline $\mathrm{H}$ & $\left(\mathrm{CH}_{2}\right)_{4}$ & $\mathrm{Mn}$ & -0.445 & 0.601 & & & & & & & \\
\hline $\mathrm{Mo}(\mathrm{NO}) \mathrm{T}_{\mathrm{p}}{ }^{*} \mathrm{Cl}$ & $\mathrm{C}_{6} \mathrm{H}_{4}$ & $\mathrm{Mn}$ & & & -0.441 & -0.554 & 1.132 & -0.411 & -0.552 & 0.962 & 1.271 \\
\hline $\mathrm{Mo}(\mathrm{NO}) \mathrm{T}_{\mathrm{p}}{ }^{*} \mathrm{Cl}$ & $\left(\mathrm{CH}_{2}\right)_{2}$ & $\mathrm{Mn}$ & & & -0.442 & -0.553 & 1.122 & -0.412 & -0.551 & 1.165 & 1.375 \\
\hline $\mathrm{Mo}(\mathrm{NO}) \mathrm{T}_{\mathrm{p}}{ }^{*} \mathrm{Cl}$ & $\left(\mathrm{CH}_{2}\right)_{3}$ & $\mathrm{Mn}$ & & & -0.443 & -0.556 & 1.172 & -0.413 & -0.552 & 1.183 & 1.368 \\
\hline $\mathrm{Mo}(\mathrm{NO}) \mathrm{T}_{\mathrm{p}}{ }^{*} \mathrm{Cl}$ & $\left(\mathrm{CH}_{2}\right)_{4}$ & $\mathrm{Mn}$ & & & -0.443 & -0.556 & 1.235 & -0.415 & -0.553 & 1.268 & 1.419 \\
\hline
\end{tabular}

$\mathrm{CV}$ measurements were made at temperature, $22 \pm 1{ }^{0} \mathrm{C}$; scan rate, $200 \mathrm{mV} / \mathrm{s}$; reading error, $\pm 10 \mathrm{mV} ; 0.1 \mathrm{M}[n$ $\left.\mathrm{Bu}_{4} \mathrm{~N}\right]\left[\mathrm{PF}_{6}\right]$ used as the base electrolyte, sample solution contained $1 \times 10^{-3} \mathrm{M}^{-1}$ of the complex. $\mathrm{E}_{1 / 2}{ }^{1}=$ reduction potential for the process $\mathrm{Mn}^{2+}+\mathrm{e}^{-} \rightarrow \mathrm{Mn}^{+} ; \mathrm{E}_{\mathrm{c}}{ }^{1}=$ cathodic peak potential for the process $\mathrm{Mn}^{2+}+\mathrm{e}^{-} \rightarrow \mathrm{Mn}^{+} ; \mathrm{E}_{\mathrm{a}}{ }^{2}=$ anodic peak potential for $\mathrm{Mn}^{2+} \rightarrow \mathrm{Mn}^{3+}+\mathrm{e}^{-} ; \mathrm{E}_{1 / 2}{ }^{3}=$ reduction potential for the process $\mathrm{Mo}(\mathrm{NO})^{3+}+\mathrm{e}^{-} \rightarrow$ $\mathrm{Mo}(\mathrm{NO})^{2+} ; \mathrm{E}_{\mathrm{a}}{ }^{4}=$ anodic peak potential for oxidation of metal ion and/or ligand; $\mathrm{E}_{\mathrm{a}}{ }^{5}=$ anodic peak potential for $\mathrm{Mn}^{2+} \rightarrow \mathrm{Mn}^{3+}+\mathrm{e}^{-} ; \mathrm{E}_{\mathrm{a}}{ }^{6}=$ anodic peak potential for oxidation of ligand.

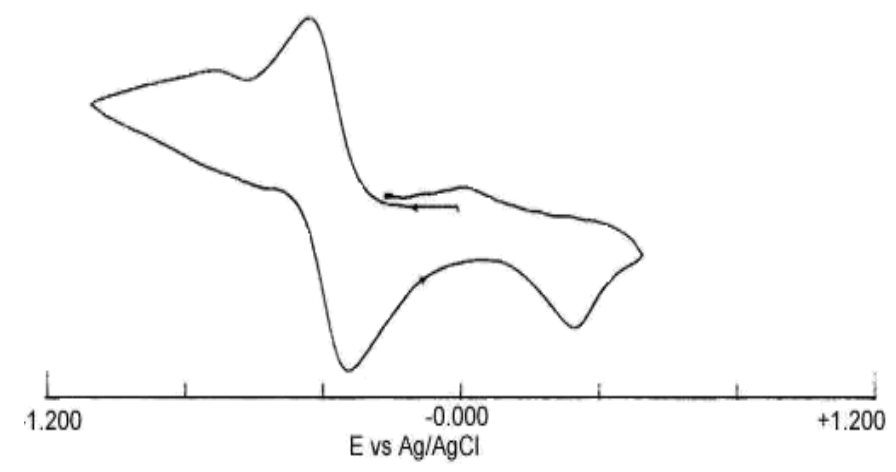

Figure 1. Cyclic voltammogram of type 3 complexes $\left[(\mathbf{3}), \mathbf{M}=\mathrm{Mn}, \mathbf{M}^{\prime}=\mathrm{H}, \mathrm{B}=\mathrm{C}_{6} \mathrm{H}_{4}\right]$ in DMSO at glassy carbon electrode (scan rate $200 \mathrm{mVs}^{-1}$ ).

A characteristic feature of these complexes is that, as the polymethylene carbon chain of the Schiff base backbone (B) lengthened, there is a very small change $(1-2 \mathrm{mV})$ in the reduction potential values for the complexes probably suggesting that the reduction orbitals of these complexes are metal-based. On scanning from 0.0 to $1.0 \mathrm{~V}$ and back, similar anodic peaks associated with $\mathrm{Mn}^{2+} \rightarrow \mathrm{Mn}^{3+}+\mathrm{e}^{-}$oxidation process were observed between 0.562 and $0.601 \mathrm{~V}$ (Table 3). The corresponding cathodic peaks were however very broad, suggesting the whole oxidation process is quasi reversible, perhaps due to the instability of the $\mathrm{Mn}^{3+}$ which may be reduced to $\mathrm{Mn}^{2+}$ as soon as it is formed in the solution. As the polymethylene carbon chain lengthens, an insignificant small shift in the reduction potentials was observed. However, the oxidation potential of the complexes varied with $10 \mathrm{mV}$ as the polymethylene carbon chain backbone lengthens, suggesting that the oxidation orbitals may be ligand-based. 
On scanning from 0.0 to $-1.5 \mathrm{~V}$ and back in $\mathrm{CH}_{3} \mathrm{CN}$, cyclic voltammograms of the $p$ bimetallic complexes $\left[(3), \mathrm{M}=\mathrm{Mn}, \mathrm{M}^{\prime}=\mathrm{Mo}(\mathrm{NO}) \mathrm{T}_{\mathrm{p}}{ }^{*} \mathrm{Cl}, \mathrm{B}=\mathrm{C}_{6} \mathrm{H}_{4},\left(\mathrm{CH}_{2}\right)_{\mathrm{n}} ; \mathrm{n}=2-4\right]$ revealed two reversible reduction waves (Figure 2).

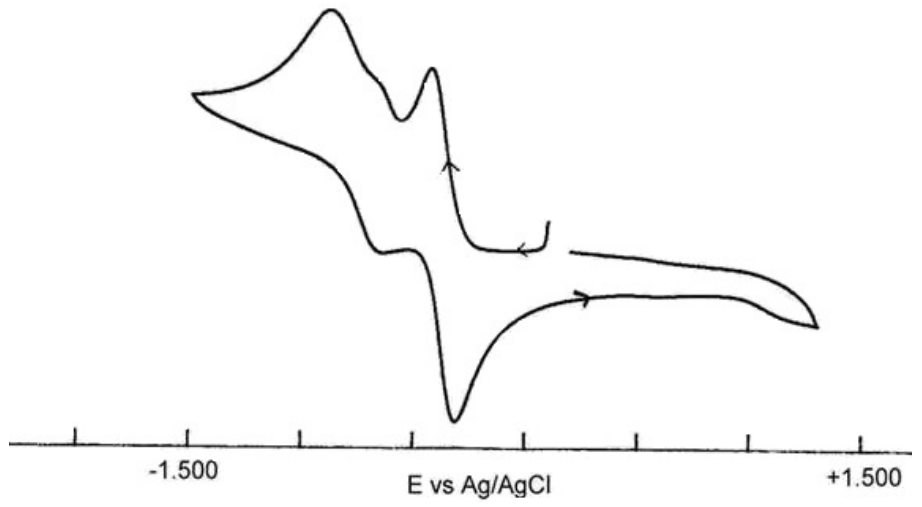

Figure 2. Cyclic voltammogram of type 3 complexes $\left[(\mathbf{3}), \mathrm{M}=\mathrm{Mn}, \mathrm{M}^{\prime}=\mathrm{Mo}(\mathrm{NO}) \mathrm{T}_{\mathrm{p}} \mathrm{Cl}, \mathrm{B}=\right.$ $\mathrm{C}_{6} \mathrm{H}_{4}$ ] in $\mathrm{CH}_{3} \mathrm{CN}$ at glassy carbon electrode (scan rate $200 \mathrm{mVs}^{-1}$.

In all the bimetallic complexes, a reversible wave associated to $\mathrm{Mn}^{2+}+\mathrm{e}^{-} \rightarrow \mathrm{Mn}^{+}$reduction process appeared in the range of -0.442 to $-0.443 \mathrm{~V}$ (Table 3 ). These potentials do not appear to vary with the length of the polymethylene carbon chain of the Schiff bases probably due to the rigid octahedral structure exhibited by the manganese(II) complexes. By comparing the voltammograms of bimetallic complexes with those of the corresponding monometallic complexes, there was no significant change in the $\mathrm{E}_{1 / 2}$-values for the reduction of $\mathrm{Mn}^{2+}$ centre in the bimetallic complexes which occur in the potential range -0.441 to $-0.445 \mathrm{~V}$. This suggests that attaching a molybdenum center to manganese(II)-Schiff base complex in type $\mathbf{3}$ complexes does not have any significant influence on the reduction potential of manganese(II) moiety.

The reduction potentials falling in the range of -0.553 to $-0.556 \mathrm{~V}$ (Table 3) and shown in Figure 2 for a typical bimetallic complex may be associated with $\mathrm{Mo}(\mathrm{NO})^{3+}+\mathrm{e}^{-} \rightarrow \mathrm{Mo}(\mathrm{NO})^{2+}$ reduction process. This reduction potential also appear to be invariant to changes in the length of the polymethylene carbon chain of the Schiff base backbone. $\Delta \mathrm{E}$-values for the reduction processes ranged from $62-68 \mathrm{mV}$ and were independent of the scan rate $(50-500 \mathrm{mV} / \mathrm{s})$ while for ferrocene/ferrocenium couple, $\Delta \mathrm{E}$-value ranged from $59-65 \mathrm{mV}$ under the same conditions. These values are consistent with the expected theoretical value of $\Delta \mathrm{E}=59 \mathrm{mV}$ for a one electron transfer process. On scanning from 0.0 to $1.5 \mathrm{~V}$ and reversing the scan direction, one broad irreversible oxidation wave was observed in the potential range $1.132 \mathrm{~V}$ to $1.235 \mathrm{~V}$ (Table 3) for all the complexes. This peak may be associated with $\mathrm{Mn}^{2+} \rightarrow \mathrm{Mn}^{3+}+\mathrm{e}^{-}$electrode reaction or oxidation of the ligand may be occurring at these potentials.

When the cyclic voltammetry of the complexes $\left[(3), \mathrm{M}=\mathrm{Mn}, \mathrm{M}^{\prime}=\mathrm{Mo}(\mathrm{NO}) \mathrm{T}_{\mathrm{p}}{ }^{*} \mathrm{Cl}, \mathrm{B}=\right.$ $\left.\mathrm{C}_{6} \mathrm{H}_{4},\left(\mathrm{CH}_{2}\right)_{\mathrm{n}} ; \mathrm{n}=2-4\right]$ was investigated in $\mathrm{CH}_{2} \mathrm{Cl}_{2}$ solvent, and on scanning from 0.0 to $-1.5 \mathrm{~V}$ and back, one broad irreversible reduction wave associated with $\mathrm{Mn}^{2+}+\mathrm{e}^{-} \rightarrow \mathrm{Mn}^{+}$appeared in the range of $-0.411 \mathrm{~V}$ to $-0.415 \mathrm{~V}$ (Table 3 ). A reversible process wave attributable to the reduction of the molybdenum center in the bimetallic complexes appear in the range of -0.551 to $-0.553 \mathrm{~V}$ (Table 3). Compared to the results obtained by Lutta et al. [15], on zinc(II) Schiff base complexes, the molybdenum center in this study reduces at a more anodic potential of $0.47 \mathrm{~V}$ (in $\mathrm{CH}_{2} \mathrm{Cl}_{2}$ ) confirming that the type of metal incorporated in the tetradentate cavity affects the reduction potential of the peripheral molybdenum center. As in $\mathrm{CH}_{3} \mathrm{CN}$, the $\mathrm{E}_{1 / 2^{-}}$ 
values of both metal centres were invariant to the changes in the length of the polymethylene carbon chain of the Schiff base backbone. On scanning from 0.0 to $1.5 \mathrm{~V}$ and reversing the scan polarity, two irreversible oxidation waves which may be associated with manganese(II) and a ligand-based oxidation processes appeared in the ranges of $0.962 \mathrm{~V}$ to $1.268 \mathrm{~V}$ and 1.271 to $1.419 \mathrm{~V}$ (Table 3), respectively.

When DPV technique was used to investigate redox behavior of monometallic and bimetallic complexes at $20 \mathrm{mV} / \mathrm{s}$ scan rate in the potential window of +0.2 to $-1.2 \mathrm{~V}$, betterresolved peaks were observed. This is in contrast to cyclic voltammograms of the complexes where the peaks were either very broad or ill-formed. The $p$-monometallic complexes $[(\mathbf{3}), \mathrm{M}=$ $\left.\mathrm{Mn}, \mathrm{M}^{\prime}=\mathrm{H}, \mathrm{B}=\mathrm{C}_{6} \mathrm{H}_{4},\left(\mathrm{CH}_{2}\right)_{\mathrm{n}} ; \mathrm{n}=2-4\right]$ show peaks in the potential range of $-0.375 \mathrm{~V}$ to -0.379 $\mathrm{V}$ (Table 4 ).

Table 4. Differential pulse voltammetric data for Type 3 complexes $\left[(\mathbf{3}), \mathrm{M}=\mathrm{Mn}, \mathrm{M}^{\prime}=\mathrm{H}\right.$ or $\mathrm{Mo}(\mathrm{NO}) \mathrm{T}_{\mathrm{p}}{ }^{*} \mathrm{Cl}, \mathrm{B}=$ hydrocarbyl] in various solvents.

\begin{tabular}{|c|c|c|c|c|c|c|c|}
\hline \multicolumn{3}{|c|}{ Compound } & DMSO & \multicolumn{2}{|c|}{$\mathrm{CH}_{3} \mathrm{CN}$} & & $\mathrm{CH}_{2} \mathrm{Cl}_{2}$ \\
\hline $\mathrm{M}^{\prime}$ & B & M & $\mathrm{E}^{1}$ & $E^{1}$ & $E^{2}$ & $E^{1}$ & $E^{2}$ \\
\hline $\mathrm{H}$ & $\mathrm{C}_{6} \mathrm{H}_{4}$ & $\mathrm{Mn}$ & -0.377 & & & & \\
\hline $\mathrm{H}$ & $\left(\mathrm{CH}_{2}\right)_{2}$ & $\mathrm{Mn}$ & -0.375 & & & & \\
\hline $\mathrm{H}$ & $\left(\mathrm{CH}_{2}\right)_{3}$ & $\mathrm{Mn}$ & -0.376 & & & & \\
\hline $\mathrm{H}$ & $\left(\mathrm{CH}_{2}\right)_{4}$ & $\mathrm{Mn}$ & -0.379 & & & & \\
\hline $\mathrm{Mo}(\mathrm{NO}) \mathrm{T}_{\mathrm{p}} \mathrm{Cl}$ & $\mathrm{C}_{6} \mathrm{H}_{4}$ & $\mathrm{Mn}$ & & -0.369 & -0.556 & -0.361 & -0.553 \\
\hline $\mathrm{Mo}(\mathrm{NO}) \mathrm{T}_{\mathrm{p}} \mathrm{Cl}$ & $\left(\mathrm{CH}_{2}\right)_{2}$ & $\mathrm{Mn}$ & & -0.367 & -0.553 & -0.362 & -0.552 \\
\hline $\mathrm{Mo}(\mathrm{NO}) \mathrm{T}_{\mathrm{p}} \mathrm{Cl}$ & $\left(\mathrm{CH}_{2}\right)_{3}$ & $\mathrm{Mn}$ & & -0.367 & -0.552 & -0.362 & -0.551 \\
\hline $\mathrm{Mo}(\mathrm{NO}) \mathrm{T}_{\mathrm{p}} \mathrm{Cl}$ & $\left(\mathrm{CH}_{2}\right)_{4}$ & $\mathrm{Mn}$ & & -0.368 & -0.553 & -0.362 & -0.552 \\
\hline
\end{tabular}

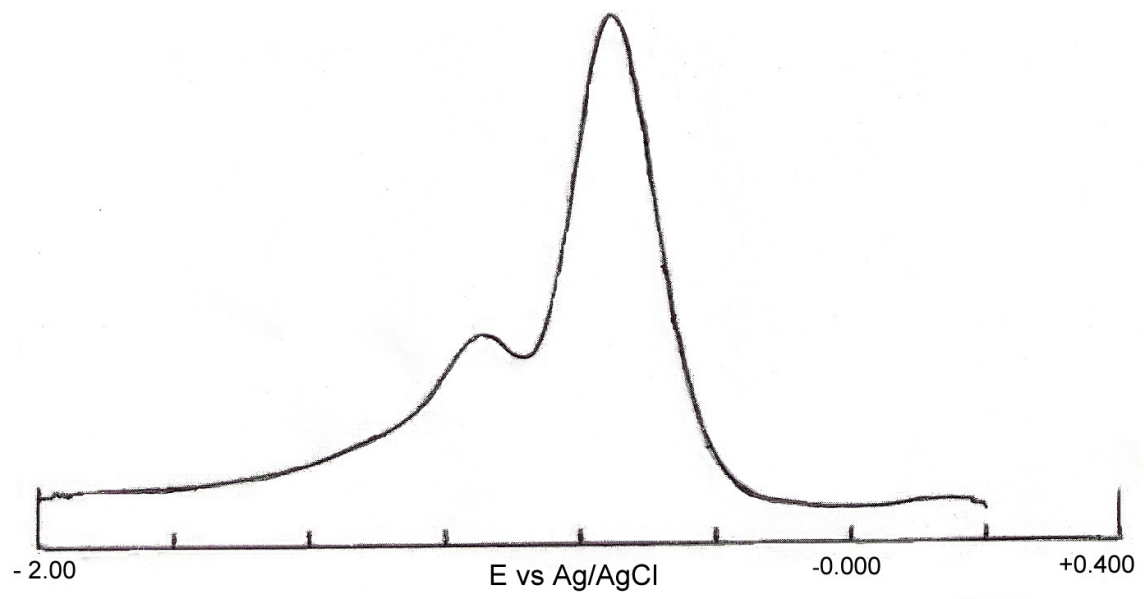

Figure 3. Differential pulse voltammogram of type $\mathbf{3}$ complexes $\left[(\mathbf{3}), \mathbf{M}=\mathbf{M n}, \mathbf{M}^{\prime}=\right.$ $\mathrm{Mo}(\mathrm{NO}) \mathrm{T}_{\mathrm{p}} \mathrm{Cl}, \mathrm{B}=\mathrm{C}_{6} \mathrm{H}_{4}$ ] in $\mathrm{CH}_{3} \mathrm{CN}$ at glassy carbon electrode (scan rate $200 \mathrm{mVs}^{-1}$ ).

The differential pulse voltammograms of the $p$-bimetallic complexes [(3), $\mathrm{M}=\mathrm{Mn}, \mathrm{M}^{\prime}=$ $\mathrm{Mo}(\mathrm{NO}) \mathrm{T}_{\mathrm{p}}{ }^{*} \mathrm{Cl}, \mathrm{B}=$ diamines] in $\mathrm{MeCN}$ exhibited two peaks (Figure 3), the peaks associated with reduction of manganese(II) occurring in the range of -0.367 to $-0.369 \mathrm{~V}$ and peaks 
associated with the reduction of the molybdenum center appear in the range of -0.552 to -0.556 $\mathrm{V}$. In $\mathrm{CH}_{2} \mathrm{Cl}_{2}$, these two peaks occurred in the range -0.361 to $-0.362 \mathrm{~V}$ and -0.551 to $-0.553 \mathrm{~V}$, respectively (Table 4$)$.

\section{CONCLUSIONS}

We have shown that compared to known monometallic and bimetallic complexes $\left[(2) \mathrm{B}=\mathrm{C}_{6} \mathrm{H}_{4}\right.$, $\left(\mathrm{CH}_{2}\right)_{\mathrm{n}} ; \mathrm{n}=2-4, \mathrm{M}=\mathrm{H}_{2}$ or $\mathrm{Cu}$ or $\mathrm{Zn}, \mathrm{M}^{\prime}=$ para or meta $\mathrm{H}$ or $\left[\mathrm{Mo}(\mathrm{NO}) \mathrm{T}_{\mathrm{p}}{ }^{*} \mathrm{Cl}\right]^{+}$and compounds $\left[(3) \mathrm{B}=\mathrm{C}_{6} \mathrm{H}_{4},\left(\mathrm{CH}_{2}\right)_{\mathrm{n}} \mathrm{n}=2-4, \mathrm{M}=\mathrm{H}_{2}\right.$ or $\mathrm{Mn}, \mathrm{M}^{\prime}=$ para or meta $\mathrm{H}$ or $\left[\mathrm{Mo}(\mathrm{NO}) \mathrm{T}_{\mathrm{p}}{ }^{*} \mathrm{Cl}\right]^{+}$ prepared in this study, changing the identity of the central metal coordinated in the Schiff base cavity has small influence on the redox and the spectroscopic behavior of the peripheral molybdenum nitrosyl group.

\section{AKNOWLEDGEMENTS}

We are indebted to the Sumika Chemical Analyzers, Japan for CHN analysis, University of Sheffield (UK) for mass spectral data, Department of Chemistry, Jomo Kenyatta University of Science and Technology for IR analysis, Pyrethrum Board of Kenya for UV/Vis analysis, and the Department of Physics, University of Nairobi for the provision of laboratory facilities to run electrochemistry of the complexes.

\section{REFERENCES}

1. Willet, R.D.; Gatteschi, D; Kahn, O. (Eds.), Magneto-structural Correlations in Exchangecouples Systems, Reidel: Dordrecht; 1985.

2. Kahn, O. Struct. Bond. (Berlin) 1987, 68, 89.

3. White, G.S.; Stephan, D.W. Inorg Chem. 1985, 25, 1499.

4. Ward, M.D. Chem. Soc. Rev. 1995, 34, 121; Kalyanasundaram, K.; Nazeeruddin, M.K. Inorg. Chim. Acta 1994, 226, 213.

5. Sauvage, J.P.; Collin, J.P.; Chambron, J.C.; Guiderez, S.; Couret, C.; Balzani, V.; Barigelletti, F.; De Cola, L.; Flamigni, L. Chem. Rev. 1994, 94, 993; Balzani, V.; Scandola, F. Supramolecular Photochemistry, Ellis Horwood: Chichester; 1991.

6. Khan, O. Molecular Magnetism, VCH Publishers: New York; 1993; McCuser, J.K.; Schmitt, E.A.; Hendrickson, D.N. in Magnetic Molecular Materials, Getterschi, D.; Khan, O.; Miller, J.S.; Palacia, F. (Eds.), NATO ASI Series E 198, Kluwer Academic Press: Dordrecht, The Netherlands; 1991; p 297; Khan, O. Pei, Y.; Journaus, Y. in Inorganic Materials, Bruce, D.W.; O’Hare, D. (Eds.), Wiley: New York; 1992; p 95.

7. Van, An. Ung.; David, A.B.; Jeffry, C.J.; Maher, J.P.; McCleverty, J.A.; Ward, M.D.; Andrew, W. Inorg Chem. 1996, 35, 5290.

8. Ward, M.D. Chem. Ind. 1997, London-0818, 640.

9. Ward, M.D. Chem. Ind. 1996, London-0805, 568.

10. Trofimenko, S. Chem. Rev. 1993, 93, 943; Kitajima, N.; Tolman, W.B. Prog. Inorg. Chem. 1995, 43, 419; McCleverty, J.A.; Pombeiro, A.J. (Eds.), Molecular Electrochemistry of Inorganic, Bioinorganic and Organometallic Compounds, Vol. 385, NATO ASI Series C., Kluwer Academic Publishers: Netherlands; 1992; p 77; Fabrizzi, L.; Poggi, A. (Eds.), Transition Metals in Supramolecular Chemistry, Vol. 448, NATO ASI Series C., Kluwer Academic Publishers: Netherlands; 1994, p 261.

11. Rowley, N.M.; Kurek, S.S.; Foulon, J.D.; Amor, T.A.; Jones, C.J.; McCleverty, J.A.; Hubig, S.M.; McInnes, E.J.L.; Payne, N.N.; Yellowless, L.J. Inorg. Chem. 1995, 34, 4414; Coe, B.J.; Hamor, T.A.; Jones, C.J.; Mcleverty, J.A.; Bloor, D.; Cross, G.H.; Axon, T.L. J. Chem. Soc. 1995, 673. 
12. McCleverty, J.A.; Charsely, S.M.; Jones, C.J.; Neaves, B.D.; Reynolds, S.J. J. Chem. Soc. Dalton Trans. 1988, 301.

13. Kagwanja, S.M.; Jones, C.J.; Maher, J.P.; McCleverty, J.A. Polyhedron 1994, 13, 2615; Kagwanja, S.M.; Jones, C.J.; McCleverty, J.A. Polyhedron 1997, 16, 1439.

14. Lutta, S.T.; Kagwanja, S.M. Trans. Met. Chem. 2000, 25, 415.

15. Lutta, S.T.; Kagwanja, S.M. Trans. Met. Chem. 2001, 26, 523.

16. Drane, A.S.; McCleverty, J.A. Polyhedron 1983, 2, 53; Reynolds, S.J.; Smith, C.F.; Jones, C.J.; McCleverty, J.A. Inorg. Syn. 1985, 23, 4.

17. Sakiyan, I.; Gunduz, N.; Gunduz, T. 2005. Trans. Met. Chem . 2007, 32, 131.

18. Kagwanja, S.M.; Jones, C.J.; Maher, J.P.; McCleverty, J.A. Polyhedron 1994, 13, 2615.

19. Liu, J.; Bowan, W.U.; Zhang, B.; Liu, Y. Turk. J. Chem. 2006, 30, 41.

20. McCleverty, J.A. Tilden Lecture, Royal Society of Chemistry: London; 1983.

21. Raman, N.; Pitchaikani, R.Y.; Kulandaisam, A. Proc. Indian Acad. Sci. 2001, 113, 183. 